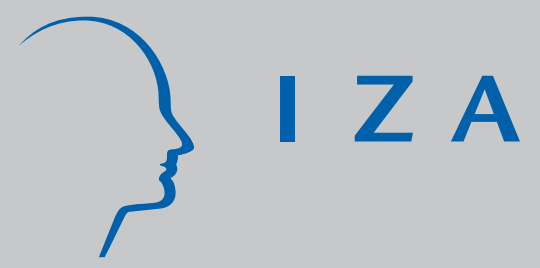

IZA DP No. 391

Employment Adjustment in Portugal:

Evidence from Aggregate and Firm Data

J ohn T. Addison

Paulino Teixeira

November 2001 


\title{
Employment Adjustment in Portugal: Evidence from Aggregate and Firm Data
}

\author{
John T. Addison \\ Moore School of Business, University of South Carolina, Free University of Bozen-Bolzano \\ and IZA, Bonn
}

Paulino Teixeira

Faculdade de Economia, Universidade de Coimbra

\author{
Discussion Paper No. 391 \\ November 2001
}

\author{
IZA \\ P.O. Box 7240 \\ D-53072 Bonn \\ Germany \\ Tel.: +49-228-3894-0 \\ Fax: +49-228-3894-210 \\ Email: iza@iza.org
}

This Discussion Paper is issued within the framework of IZA's research area Mobility and Flexibility of Labor Markets. Any opinions expressed here are those of the author(s) and not those of the institute. Research disseminated by IZA may include views on policy, but the institute itself takes no institutional policy positions.

The Institute for the Study of Labor (IZA) in Bonn is a local and virtual international research center and a place of communication between science, politics and business. IZA is an independent, nonprofit limited liability company (Gesellschaft mit beschränkter Haftung) supported by the Deutsche Post AG. The center is associated with the University of Bonn and offers a stimulating research environment through its research networks, research support, and visitors and doctoral programs. IZA engages in (i) original and internationally competitive research in all fields of labor economics, (ii) development of policy concepts, and (iii) dissemination of research results and concepts to the interested public. The current research program deals with (1) mobility and flexibility of labor markets, (2) internationalization of labor markets and European integration, (3) the welfare state and labor markets, (4) labor markets in transition, (5) the future of work, (6) project evaluation and (7) general labor economics.

IZA Discussion Papers often represent preliminary work and are circulated to encourage discussion. Citation of such a paper should account for its provisional character. 
IZA Discussion Paper No. 391

November 2001

\section{ABSTRACT \\ Employment Adjustment in Portugal: Evidence from Aggregate and Firm Data}

This paper examines the pattern of employment adjustment in Portugal. First, the issue is addressed using a long time series of aggregate data. Although the employment data show persistence, there is nonetheless a fairly rapid rate of employment adjustment. Second, a much shorter time series of firm data is used to check the persistence detected at aggregate level, and also to examine the contribution of atypical work over the cycle. Consistent with the aggregate evidence, and despite stronger employment inertia, there is no suggestion in the firm panel that labour demand is cyclically unstable.

JEL Classification: $\quad$ C22, C23, J23, J32

Keywords: Employment adjustment, employment protection, labor demand, errorcorrection model, panel estimation

John T. Addison

Department of Economics

Moore School of Business

University of South Carolina

Columbia, SC 29208

U.S.A.

Tel.: +1 (803) 777-4608

Email: ecceaddi@darla.badm.sc.edu 


\section{Introduction}

There has long been interest in the process of labour market adjustment. Thus, the presence of firm-specific training introduces employment adjustment costs, thereby ensuring that firms will not expand/contract employment in immediate response to increased/decreased sales. Similarly, there are aher elements of fixity produced by the costs of the personnel function and government-mandated benefits such as health and pension programs. Most recently of course, attention has focused upon firing costs rather than hiring costs. Much effort has been expended on isolating the effect of employment protection on the levels of employment (and unemployment) and on the speed of adjustment of labour demand to changes in output (see, for example, Burgess, 1988; Bentolila and Bertola, 1990; Hamermesh, 1993; Abraham and Houseman, 1994; Scarpetta, 1996; Garibaldi, 1998; OECD, 1999; Addison, Teixeira, and Grosso, 2000; Blanchard and Portugal, 2001). It is conventional to argue that employment protection lowers the speed of adjustment of employment to changes in output, even if the effects on economic aggregates are ambiguous a priori principally because of the opposing effects on hires and dismissals.

In the present exercise, we are not directly concerned with measuring the impact of employment protection per se. Rather, our concern is with the broad analytics of employment adjustment in a country - Portugal - often portrayed as an exemplar of labour market inflexibility. Our analysis of aggregate data, which focuses on the statistical properties of the employment and output time series in addressing the pattern of long- and short-run employment adjustment, provides scant evidence of terminal inertia. Indeed, employment is shown to adjust comparatively rapidly to desired levels. Our more detailed analysis of labour demand at firm level fulfils two functions. First, apart from providing estimates of real wage elasticities, inter al., it also provides a rough and ready check on the inertia in employment adjustment observed in the aggregate series. Second, in distinguishing whether a firm is in recession or expansion, it tests for the cyclical stability of labour demand; specifically, a reduction in employment persistence during upturns. The latter point is highly relevant 
because of recent research for neighbouring Spain pointing to cyclical instability in labour demand produced by the use of temporary work or, more accurately, the deployment of fixedterm contracts with negligible to nonexistent firing costs (e.g. Bentolila and Blanchard, 1990; Bentolila and Saint-Paul, 1993; Bentolila and Dolado, 1994). The argument is that recourse to such atypical workers means that firms will be less reluctant to hire in the upturn, so that employment should evince less persistence. Consistent with our aggregative evidence we find no evidence of instability in the demand curve. Although we are less than surprised by this result, given the comparatively low incidence of fixed-term contracts in Portugal (circa 14\%, as compared with over $30 \%$ in Spain), the relative ease with which such contracts can be used would again seem to challenge the view that open-ended employment in Portugal is tightly regulated.

The plan of the paper is as follows. Section 2 introduces the aggregate data as well as the firm panel. Results for the two datasets are separately considered in sections 3 and 4 . The threads of the preceding empirical arguments are drawn together in section 5 .

\section{The Data}

Our time-series data on employment and output at manufacturing industry level cover the period 1977:1-1977:4, and were collected from the Portuguese Statistical office (INE). Specifically, the output series were drawn from Contas Nacionais Trimestrais - INE (May, 1992; June 1998), while the employment data were taken from Inquérito Permanente ao Emprego, Inquérito ao Emprego, and Estatísticas do Emprego. These employment series required some manipulation, however, to control for several statistical breaks. In our procedure, the original quarterly series published by the INE were adjusted by the annual series published by Bank of Portugal (1997) assuming the same original quarterly shares. In addition, because manufacturing employment was available on a semi-annual basis between 1977 and 1983, quarterly figures for this period were computed using quarterly employment indices for the manufacturing sector published by the Portuguese Ministry of Labour. 
Our labour demand model, specified in section 3, also requires information on input prices of labour and energy. Between 1977 and 1990, manufacturing wages are given by an index of quarterly average earnings published by the Ministry of Labour. This series was discontinued in 1991. Thereafter, the wage information pertains to negotiated wages at industry level, which is used to complete the series up to 1997. The input price of energy is given by the deflator of the energy sector and was computed from Contas Nacionais Trimestrais (valores sectoriais). The relevant series are presented in panel (a) of Figure 1 and will be further commented in section 3 .

The analysis of employment adjustment at firm level uses an initial sample of 1,970 firms taken from the data base of balance sheet records (Central de Balanços) of the Bank of Portugal for the period 1990-1997. The data base contains information on sales, cost of materials, labour costs (specifically, the wage bill), fixed and intangible assets, and the level of employment. All nominal variables are expressed in real terms (1995 prices) using the GDP deflator. The stock of capital was computed using a recursive "last in-first out" revaluation method that takes account of economic depreciation over time. Our calculations follow the procedure described by Bentolila and Saint-Paul (1992, p. 146) and involves computing (a) the initial market value of the capital stock (tangible assets) for each firm at the beginning of the period (this calculation assigns a given average depreciation rate, while the price of capital is proxied by the deflator of gross fixed capital formation), and (b) the real capital stock for successive years, based on the initial market value computed in (a) plus investment minus annual depreciation.

We applied several filters to the original sample, resulting in a balanced panel of 1,552 manufacturing firms (excluding the oil refining sector). All firms in the sample have at least five paid employees and both the volume of sales and the cost of materials were restricted to 
at least 1,000 contos (thousand escudos) a year. The input price of materials and labour are obtained by dividing the relevant total costs by the number of employees.

[Table 1 near here]

Panel (a) of Table 1 provides descriptive statistics for the relevant variables. The average firm size is 100.5 employees, but $70 \%$ of the firms have less than 75 employees and total sales do not exceed 400 thousand contos for one half of the sample. The distribution of firms, both in terms of output and employment, is left skewed. However, given the non-random sampling of the dataset (Central de Balanços), medium and large firms are over-represented in the data base. ${ }^{1}$ The average growth rate of sales in the sample period $(0.4 \%$ per year) is smaller than for the entire manufacturing sector $(0.8 \%)$. The loss of manufacturing jobs is also smaller in the firm sample, but, as shown in panel (a) of Appendix Table 1, the pattern over the period is similar. Labour costs per employee show an upward trend, while the growth in output per employee seems to follow the pattern of sales growth. Finally, panel (c) of Table 1 shows the proportion of firms in expansion/recession. The large majority of firms had slumping sales between 1991 and 1993. Firms were hit particularly hard in 1993, with an average (unweighted) sales growth of $-7 \%$ and $70 \%$ of the sample in recession. Expansion started in 1994, and from that year on a majority of the firms in the sample were in expansion. The average (unweighted) growth in sales for the period 1994-1997 was 1.5\%.

\section{Employment Adjustment at Manufacturing Industry Level}

First consider the time series properties of output $y$, employment $l$, and the relative input price of energy $p / w$ (the input price of energy divided by real wages) over the sample period 1977:1-1997:4. The relevant series are presented in Figure 1, in levels and in first and fourth differences. Inspection of the panel (b) of the figure seems to indicate that the series are stationary after first differencing, while the fourth differences, reported in panel (c), suggest a close relationship between employment and output, with an upward swing in the late 1980s and two recessions in the early 1980s and 1990s. ${ }^{2}$ 
[Figure 1 and Table 2 near here]

Formal unit root tests are presented in Table 2. The first column shows the results from the ADF test on levels of the variables. The null hypothesis is that the series are integrated of order one at the zero frequency (i.e. in the long run). In none of the cases does the $t_{\mathrm{ADF}}$ statistic exceed (in absolute value) the critical value. To further check on the presence of a single unit root, we applied the Dickey-Pantula (1987) test which first tests for two unit roots (second column of Table 2) and then for a single unit root (third column). Based on these tests, employment, output, and the relative price of energy are rejected as I(2) but not as I(1). ${ }^{3}$ Accordingly, the proper way to proceed is through cointegration analysis, because standard OLS methods using levels of employment and output will yield non-consistent estimators (i.e. the associated standard errors are not asymptotically convergent). In this case, the level variables included in the regression are I(1), and the estimated relationship - the cointegrating relationship - can be interpreted as the long-run equilibrium if the estimated residuals are stationary, or $\mathrm{I}(0)$. Simply running a model in first differences - which are $\mathrm{I}(0)$ - will introduce misspecification bias by failing to account for the underlying relationship between the levels of the variables. The model in differences must then be replaced by an error correction model (ECM) that includes all differenced variables as well as an error correction term (i.e. the past deviations from the long-run equilibrium).

To test whether employment and output are cointegrated or not - that is, whether there is any vector $\alpha$ such that $z_{t}-\alpha X_{t}=\mu_{t}$ is $\mathrm{I}(0)-$ we begin with the static employment-output relation including a trend term and the relative price of energy (all variables are in logs):

$$
l_{t}=4.33+0.396 y_{t}-0.005 T-0.034(p / w)_{t} .
$$


On the basis of the ADF test, the estimated residuals from this equation are rejected as I(1) (the Mackinnon critical value for the ADF cointegrating test at 5\% is -3.78). We note parenthetically that implementation of the $Z_{\alpha}$ test described by Phillips and Ouliaris (1990), a procedure that, in comparision with the $\mathrm{ADF}$ test has revealed superior power properties (e.g. Haug, 1996), failed to reject the null of no cointegration (results available on request). This conflicting evidence should not be surprising, however, given the low power of residualbased cointegrating tests (see, for example, Maddala and Kim, 1998, for an useful survey). The use of the Johansen methodology to search for the cointegrating employment-output vector in the level of the variables was also inconclusive. We believe that a thorough analysis of the employment-output relationship (including the use of the VAR approach) requires wider set of variables. Unfortunately, the length of the time-series (1977:1-1997:4) precluded our assembling good data on additional variables. In any case, it seems that the evidence provided below on nonlinear one-stage and two-stage Engle-Granger ECM models reasonably supports the hypothesis of cointegration of the variables included in the model. Indeed, it is wellknown that the ECM model not only allows precise short-run parameter estimation, but also provides cointegrating tests (called ECM-based cointegrating tests) that have been shown to have superior power properties to the residualbased tests (see Kremers, Ericsson, and Dolado, 1992; Banerjee, Dolado, and Mestre, 1998).

We thus proceed with the second-stage ECM estimation. Before doing so, however, we pause to briefly comment on the parameters of the static cointegrating regression reported in equation (1). ${ }^{4}$ As expected, there is a negative trend in manufacturing employment of -0.005 per quarter, which implies an annual decrease of $2 \%$. Both the output and input price elasticities are very small, with the output elasticity of 0.4 pointing to the presence of increasing returns to scale in manufacturing, while an increase in the relative price of energy is predicted to lower the demand for labour. 
The second-stage ECM model can now be specified as:

$$
\Delta l_{t}=\alpha_{0}+\sum_{i=1}^{4} \alpha_{i} \Delta l_{t-i}+\sum_{j=1}^{n} \sum_{i=0}^{4} \beta_{j} \Delta x_{j, t-i}+\lambda e c m_{t-1}+\varepsilon_{t},
$$

where the $e c m_{t}$ term represents the residuals from equation (1) (i.e. $e c m_{t}=l_{t}-\hat{l}_{t}$ ) and $x_{j, t}$ denotes the right-hand side variables included in the labour demand model. Using a generat to-specific approach, the fitted regression is then: ${ }^{5}$

$$
\begin{array}{rlcc}
\Delta l_{t}= & 4.30 \Delta l_{t-1}+0.398 \Delta l_{t-2}-0.229 \Delta y_{t-2}-0.520 \Delta e c m_{t-1}-0.0005 \\
(0.101) & (0.104) & (0.105) & (0.084)
\end{array}
$$

$\mathrm{T}=67 ; \mathrm{R}^{2}=0.54 ; \mathrm{SER}=0.006 ; \mathrm{LM}(4)=10.60 ; \mathrm{NORM}=0.77 ; \mathrm{ARCH}(4)=0.94 ; \mathrm{WHITE}(4)=0.58 ; \mathrm{RESET}=0.034$

Equation (2') shows a well-determined process of adjustment to the long-run equilibrium; that is, the error correction term is strongly significant (the critical value for $\mathrm{t}_{\mathrm{ECM}}$ test at $1 \%$ is 4.32), ${ }^{6}$ large in absolute value, and of the expected negative sign. Fitting a nonlinear one-stage ECM model to the data also rejected the hypothesis that $\lambda$ is insignificantly different from zero (i.e. again indicating that the variables are cointegrated). ${ }^{7}$ In this case, the $\mathrm{t}_{\mathrm{ECM}}$ was equal to -5.41 and the critical value at $1 \%$ is -4.60 . (The critical values for this test are provided by Banerjee, Dolado, and Mestre, 1998.)

As usual, an error correction term with a minus sign means that employment tends to decrease when $\mathfrak{t}$ is higher than its long-run level. Although crucial in determining the short-run dynamics of the employment-output relationship, the remaining coefficients in (2') are not easy to interpret given the restrictions introduced to obtain a parsimonious empirical model. We will therefore provide further analysis of the dynamic adjustment of labour demand by focusing on the decomposition of the long- and short-run effects, that is, by examining the fitted values of the employment series generated by the labour demand model. 
Thus, following Andersen and Hylleberg (2000), we first solve model (2') to obtain the fitted values of employment $\hat{l}_{t}$. Next, since equation (2') is restricted to follow the long-run cointegrating relationship, we compare the actual employment level $l_{t}$ with $\hat{l}_{t}$ and $\hat{l}_{t}^{L R}$ (the latter being obtained from the long-run cointegrating relationship) to compute the short-run component of employment $\hat{l}_{t}^{S R}$, where $\hat{l}_{t}^{S R}=\hat{l}_{t}-\hat{l}_{t}^{L R}$.

Panels (a) and (b) of Figure 2 indicate the good fit of the model. Both the long-run prediction $\left(\hat{l}_{t}^{L R}\right)$ and the prediction incorporating the long-run and the short-run components of the model $\left(\hat{l}_{t}\right)$ show a high degree of accuracy. And while the $\hat{l}_{t}^{S R}$ series in panel (c) seems to suggest some noise, there is no clear pattern of inertia arising from this series, which can be explained by the sizeable error correction term. (Analysis of the correlogram of the $\hat{l}_{t}^{S R}$ series also shows little evidence of inertia in the short-run part of the model.)

[Figure 2 and Table 3 near here]

The role of the short- run versus the long-run can be illustrated by regressing observed employment levels on the estimated long-run and short-run series. As Table 3 shows, the OLS regressions of $l_{t}$ on $\hat{l}_{t}$ and $\hat{l}_{t}^{L R}$ confirm the close association between these two series. The coefficient estimates of $\hat{l}_{t}$ and $\hat{l}_{t}^{L R}$ are not significantly different from unity, while the constant term in both regressions is not statistically different from zero. As expected, the constant term is only statistically significant in the regression of $l_{t}$ on $\hat{l}_{t}^{S R}$. Clearly, most of the labour adjustment is of the long-run type, with short-run component of the model explaining very little of total employment levels $\left(\mathrm{R}^{2}=0.01\right)$. Indeed, controlling for the longrun component of the model, the correlation between $l_{t}$ and $\hat{l}_{t}^{S R}$ is only 0.11 , which means that the short-run part is largely unable to explain the variation in $l_{t}$ which is not explained by the long-run component. Therefore, although the regression of $l_{t}$ on $\hat{l}_{t}^{L R}$ and $\hat{l}_{t}^{S R}$ shows 
complementarity between the short- and long-run parts of the model - both coefficients are positive and significant - the very high partial squared correlation of the long-run coefficient (partial $\mathrm{R}^{2}=0.93$ ) shows that this effect is clearly dominant.

\section{Employment Adjustment at the Firm Level}

We now consider labour adjustment (measured by net employment changes) at the level of the firm. The framework is one in which firms are assumed to respond to common (aggregate) demand shocks and to firm-specific shocks. Although the time span of the firm panel series is substantially shorter than for the time series data - just eight years of annual data as compared with twenty years of quarterly data - the richer information available at this level allow us to study reactions to changes in demand in greater detail.

The first task is to estimate an overall measure of employment persistence that is comparable with the time-series evidence assembled earlier. The next task is to test whether there is any distinct pattern of labour adjustment over the cycle. As shown by Bentolila and Saint-Paul (1992), if adjustment through regular open-ended employment is difficult and costly, then firms will tend to use proportionally more (less) fixed-term contracts during expansions (recessions), and hence larger (smaller) wage elasticities will be observed during good (bad) years, because the wage elasticity is presumably larger for such flexible work. By the same token, we should observe larger cyclical variability of employment (i.e. greater employment fluctuation) when adjustment through flexible work is possible, which can be assessed by looking at the impact of unexpected changes in output during unfavourable and favourable states of nature. The expected result will be a higher shock elasticity in expansion. Again, if firms use atypical workers in the postulated manner, we should also observe lower employment persistence during expansions.

Given these hypotheses, the empirical model implemented here is designed to address (a) input price elasticities (labour, capital, and materials), (b) the elasticity of labour to demand 
shocks, and (c) the degree of inertia in labour adjustment and the process of adjustment over the cycle. In other words, our analysis seeks to study the impact of the cycle on the determinants of labour demand: factor prices, shocks, and lagged employment.

The dynamic specification of labour demand (total employment) contains the input prices of labour and materials, the stock of capital, and one lagged employment term to control for sluggish labour adjustment. Changes in labour demand are also a function of specific and general demand shocks. The former are proxied by the $(\log )$ change in firms' sales, and the latter by time dummies.

Formulated in logarithms, the model can be specified as follows: ${ }^{8}$

$$
l_{i t}=\lambda l_{i t-1}+\beta^{\prime}(L) X_{i t}+u_{i}+v_{t}+e_{i t}
$$

where $L$ is the lag operator and $\beta$ is the vector of coefficients of exogenous variables. Note that the input prices of labour and materials are in fact treated as endogenous variables, given that they are obtained by dividing total costs by total employment and because under usual wage bargaining settlements wages and employment are jointly determined. The lagged dependent variable and input prices have thus been instrumented. We use lags of these variables dated ( $\mathrm{t}-2)$ and earlier as instruments. All unobservable variables specific to the individual firm are mirrored in the time-invariant firm-specific component $u_{i}$, macroeconomic events (aggregate demand shocks) specific to a given year are represented by $v_{t}$, and $e_{i t}$ is a white noise residual.

Finally, to analyse the process of labour adjustment over the cycle, a cycle dummy is interacted with all right-hand variables in (3). It is defined as 1 if the firm is in expansion and 0 if the firm is in recession. In our calculations, a firm is in expansion if the log growth rate of sales is higher than $2 \%$. If the growth rate is lower than $1 \%$, then it is in recession. A firm is 
also in expansion if the growth rate of sales is between $1 \%$ and $2 \%$ and it is coded in expansion in the previous period. This information is summarised in panel (c) of Table 1 .

Given the presence of lagged dependent variables on the right hand side of equation (3), which would produce biased and inconsistent estimates, we cannot use the usual panel estimation techniques. Instead, we used the Generalised Method of Moments (GMM) estimator developed by Arellano and Bond (1991). This methodology extends the first difference instrumental variables method suggested by Anderson and Hsiao (1981) to dynamic fixed-effects models, and yields asymptotic standard errors that are robust to general cross-section and time-series heteroskedasticity under the null hypothesis of no serial correlation in the errors. To test this hypothesis, Arellano and Bond have developed a firstand second-order serial correlation test statistic based on the GMM residuals.

The fitted version of equation (3) - in first differences - is presented in Table 4. Note that due to double differencing of sales and the definition of the variables used in the model the data refer to 1993-97. In fact, we also excluded 1993 from the sample period to avoid computation of a negative shock elasticity - recall that the average sales growth in 1993-1997 is -0.04. In any event, the estimated parameters were not sensitive to this exclusion.

The regression statistics do not seem to suggest any specification problems; for example, the assumption of serially uncorrelated errors appears adequate. Indeed, the null of no residual autocorrelation (the $\mathrm{m}_{2}$ test) is not rejected, while the Sargan test validates the selected set of instruments. In turn, the joint insignificance of the coefficients included in the regression is clearly rejected by the Wald test.

The lagged employment variable has a coefficient of 0.75 - employment at lag 2 is insignificant. This implies a mean adjustment lag of 3 periods (years). Comparing this estimate with the time-series results, we can conclude that panel estimation with annual data 
yields stronger employment inertia. (The derived speed of adjustment of 52\% per quarter obtained in equation (2') implies a mean adjustment lag of (1-0.52)/0.52, or 0.9 quarters.)

This estimate of employment inertia in the firm panel is lower than that reported by Bentolila and Saint-Paul (0.86) for Spain and higher than of Arellano and Bond (0.68) for the U.K. This seems sensible. Also sensible is the positive coefficient for the growth rate of sales (the shock variable) and the negative coefficients for labour costs and the price of materials. The coefficient for capital is positive but not statistically significant.

The long-run employment elasticities with respect to wages, input prices, and shocks in demand, presented in Table 4, are in general quite small, but need to be interpreted with caution. Thus, the measured wage elasticity is a wage bill elasticity rather than a wage rate elasticity, so that any measurement error will presumably induce upward bias in the estimated parameter. The same can be said of the price of materials, obtained by dividing total costs by total employment. Although these variables have been instrumented, the procedure is only as good as the data. The interpretation of the shock elasticity, which is quite small due to the low average growth (1.5\%) over the sample period, is also problematic because the shock (the log change in sales) captures the effects arising both from changes in output and in liquidity constraints (Nickell and Waldhwani, 1989). In general terms, the elasticity estimates are now lower (in absolute value) than those found by in Bentolila and Saint-Paul and larger than those reported by Arellano and Bond.

Finally, the effect of the cycle is indicated in the second column of the table. There is no evidence that labour demand is unstable over the cycle; that is, the cycle impacts neither the lagged employment term nor the long-run elasticities. The coefficient of the shock variable remains very large, positive, and statistically significant, but firms do not show any distinct pattern of labour adjustment during recessions and expansions. This result is remarkably at odds with the evidence for Spain. In our view, this result is due to less restrictive conditions 
on the use open-ended employment in Portugal which in turn implies a much less prominent role for atypical work. This conjecture is possibly confirmed by the fact that the proportion of flexible workers in Portugal is only one third the Spanish level, and by the result that nonpermanent and permanent work seem to behave as complements rather than substitutes in response to output changes (Teixeira, 1998).

\section{Conclusions}

This paper has examined both aggregate and micro datasets for Portuguese manufacturing to address the issue of speed of employment adjustment. The backdrop is that of an allegedly highly sclerotic labour market. Our aggregative analysis used quarterly manufacturing industry data and focused on the behaviour of the relevant employment and output time-series over a period of almost two decades. We reported evidence of a firm long-run relationship between employment and output. Although the implied long-run employment-output elasticity is rather small (0.4), the existence of a stable relationship between output and employment appears to be good news from a labour market perspective in circumstances where, as it is the case here, the cointegrating relationship is accompanied by a welldetermined process of adjustment to the long-run estimated equilibrium. We separately analysed the dynamics of the labour market through a decomposition of the long-run and short-run effects, finding that most labour adjustment was of the long-run type.

The second component of the paper was also concerned with employment inertia, this time using annual data collected at firm level. Although the time interval was in this case much shorter, the value added of the firm panel was that it facilitated a more comprehensive treatment of the reaction of firms to demand shocks and the phase of the cycle by virtue of having richer information on input prices (especially labour costs). As expected, the annual data yielded a lower speed of labour adjustment to change in output demand. The more interesting result, however, was the absence of any statistically significant effect of the cycle variable on the behaviour of labour demand. Juxtaposed against the findings of Bentolila and 
Saint-Paul (1992), obtained from similar methods and data, our results suggest that atypical work plays a much less prominent role in employment adjustment in Portugal than in Spain. This evidence also has a bearing on the sclerosis conjecture.

\section{Endnotes}

1. Employment shares, in panel (b) of Appendix Table 1, do not point to any obvious sectoral bias in the selected sample.

2. Since it was not possible to obtain seasonally unadjusted series for all selected variables, we applied the seasonal filter $\left(1+\mathrm{L}+\mathrm{L}^{2}+\mathrm{L}^{3}\right)$ to the original series.

3. To test the null of a unit root against the alternative of a trend-stationary series with a single and endogenous breakpoint, we also applied the methodology described by Zivot and Andrews (1992). From this procedure, we obtain confirmation that the series have a unit root, even allowing for segmented trends in the data. These results are available on request.

4. The t-statistics obtained from standard OLS estimation of (1) cannot be applied to construct usual confidence intervals because the variables are $\mathrm{I}(1)$, violating the constancy of the variance of the residuals. The parameter estimates can nevertheless be used to derive long-run labour demand elasticities provided that the variables are cointegrated, even if no dynamics are specified in the model.

5. ARCH is the test for autoregressive conditional heteroscedasticity, NORM is the JarqueBera test for the normality of the residuals, RESET is the Ramsey first-order test for functional form misspecification, and WHITE is White's test for heteroscedasticity based on the squares of the regressors.

6. The standard unit root critical values are not valid because the $t_{\mathrm{ECM}}$ statistics contains the estimated residuals from the first-stage static regression. We use Mackinnon's critical values (Davidson and Mackinnon, 1993, Table 20.2).

7. The specification for the nonlinear ECM model is

$\Delta l_{t}=\mu+\lambda\left[l_{t-1}-\sum_{j=1}^{n} \alpha_{j} x_{j, t-1}-\beta T\right]+\sum_{i=1}^{k} \delta_{i} \Delta l_{t-i}+\sum_{j=1}^{n} \sum_{i=0}^{r} \gamma_{j i} \Delta x_{j, t-i}+\varepsilon_{t}$.

These results are available on request.

8. Sources of this familiar exercise are Nickell (1984), Layard and Nickell (1986), Dolado (1987), and Bentolila and Saint-Paul (1992). 


\section{References}

Abraham, K.G. and Houseman, S.N. (1994), Does Employment Protection Inhibit Labor Market Flexibility? Lessons from Germany, France and Belgium, in R.M. Blank (ed.), Social Protection versus Economic Flexibility - Is There a Tradeoff?, University of Chicago Press, Chicago, Illinois.

Addison, J.T., Teixeira, P. and Grossso, J-L. (2000), The Effect of Dismissals Protection on Employment: More on a Vexed Theme, Southern Economic Journal 67, 105-122.

Andersen, T. and Hylleberg, S. (2000), Sources of Persistence in Employment Adjustment Denmark 1974-93, Oxford Economic Papers 52, 72-95.

Anderson, T.W. and Hsiao, C. (1981), Formulation and Estimation of Dynamic Models with Error Components, Journal of the American Statistical Association 76, 598-606.

Arellano, M. and Bond, S. (1991), Some Tests of Specification for Panel Data: Monte Carlo Evidence and an Application to Employment equations, Review of Economic Studies 58, 277 297.

Banco de Portugal (1997), Séries Longas para a Economia Portuguesa, Banco de Portugal, Lisboa.

Banerjee, A., Dolado, J. and Mestre, R. (1998), Error-Correction Mechanism Tests for Cointegration in a Single-Equation Framework, Journal of Time Series Analysis 19, 267-283.

Bentolila, S. and Bertola, G. (1990), Firing Costs and Labour Demand: How Bad is Eurosclerosis?, Review of Economic Studies 57, 381-410.

Bentolila, S. and Blanchard, O. (1990), Spanish Unemployment, Economic Policy, April, 233-281.

Bentolila, S. and Dolado, J. (1994), Labour Flexibility and Wages: Lessons from Spain, Economic Policy, April, 55-99.

Bentolila, S. and Saint-Paul, G. (1993), The Macroeconomic Impact of Flexible Labour Contracts, with an Application to Spain, European Economic Review 36, 1013-1053.

Blanchard, O. and Portugal, P. (2001), What Hides Behind an Unemployment Rate: Comparing Portuguese and U.S. Labor Markets, American Economic Review 91, 187-207.

Burgess, S. 1988. Employment Adjustment in U.K. Manufacturing, Economic Journal 98, 81-103.

Davis, S.J. and Haltiwanger, J. (1999), On the Driving Forces Behind Cyclical Movements in Employment and Job Reallocation, American Economic Review 89, 1334-1258.

Dickey, D.A. and Pantula, S.G. (1987), Determining the Order of Differencing in Autoregressive Processes, Journal of Business and Economic Statistics 5, 455-463.

Dolado, J. (1987), Intertemporal Employment and Pricing Decision Rules in UK Manufacturing, Applied Economics Discussion Paper 18, Oxford University. 
Garibaldi, P. (1998), Job Flow Dynamics and Firing Restrictions. European Economic Review 42, 245-276.

Haug, A. (1996), Tests for Cointegration: a Monte Carlo Comparison, Journal of Econometrics 71, 89-115.

Hamermesh, D.S. (1993), Employment Protection: Theoretical Implications and Some U.S. Evidence, in C.F. Buechtemann (ed.), Employment Security and Labour Market Behaviour Interdisciplinary Approaches and International Evidence, ILR Press, Ithaca, New York.

Kraft, K. (1993), Eurosclerosis Reconsidered: Employment Protection and Work Force Adjustment in West Germany, in C.F. Buechtemann (ed.), Employment Security and Labor Market Behavior - Interdisciplinary Approaches and International Evidence, ILR Press, Ithaca, New York.

Kremers, J., Ericsson, N. and Dolado, J. (1992), The Power of Cointegration Tests, Oxford Bulletin of Economics and Statistics 54, 325-348.

Layard, R. and Nickell, S. (1986), Unemployment in Britain, Economica 53, Supplement, 5121-5169.

Maddala, G.S. and Kim. I.-M. (1998), Unit Roots, Cointegration and Structural Change, Cambridge University Press, Cambridge.

Nickell, S. (1978), Fixed Costs, Employment and Labour Demand over the Cycle, Economica 45, 329-345.

Nickell, S. and Wadhwani, S. (1989), Employment Determination in British Industry: Investigations Using Micro Data, Centre for Economic Policy Research, Discussion Paper 320.

Nickell, S. (1984), An Investigation of the determinants of Manufacturing Employment in the United Kingdom, Review of Economic Studies 51, 529-557.

OECD (1999), Employment Protection and Labour Market Performance, Employment Outlook, June, 49-132.

Phillips, P.C.B. and Ouliaris, S. (1990), Asymptotic Properties of Residual Based Tests for Cointegration, Econometrica 58, 165-193.

Scarpetta, S. (1996), Assessing the Role of Labour Market Policies and Institutional Settings on Unemployment: A Cross-Country Study, OECD Economic Studies 26, 42-98.

Teixeira, P. (1998), Contratos a Prazo, Emprego Permanente e Ouput: Uma Relação de Longo Prazo?, Estudos de Economia 18, 211-228. 
Table 1: Descriptive Statistics

(a) Employment, Output (Sales), and Capital

\begin{tabular}{lrrrrrr}
\hline \multicolumn{1}{c}{ Variable } & Mean & Std. Dev. & Min. & Max. & Average growth rates \\
& & & & & & \\
Employment & 100.5 & 209.5 & 5 & 3335 & $-1.9 \%$ & $-2.6 \%$ \\
Sales & 1,382 & 5,543 & 5,2 & 189,000 & $0.4 \%$ & $0.8 \%$ \\
Capital & 1,393 & 9,077 & 0.05 & 341,000 & $0.6 \%$ & - \\
\hline
\end{tabular}

(b) Annual Growth Rates in the Sample (in \%)

\begin{tabular}{|c|c|c|c|c|c|}
\hline & Employment & Labour costs & Sales & $\begin{array}{l}\text { Sales per } \\
\text { employee }\end{array}$ & $\begin{array}{l}\text { Labour costs } \\
\text { per employee }\end{array}$ \\
\hline \multicolumn{6}{|l|}{ Year } \\
\hline 1990 & - & - & - & - & - \\
\hline 1991 & -1.2 & 3.8 & -3.0 & -1.9 & 5.0 \\
\hline 1992 & -2.4 & 0 & -4.7 & -2.4 & 2.4 \\
\hline 1993 & -3.4 & -2.6 & -4.9 & -1.5 & 0.8 \\
\hline 1994 & -2.8 & -1.7 & 4.6 & 7.6 & 1.1 \\
\hline 1995 & -0.9 & -0.6 & 3.8 & 4.8 & 0.3 \\
\hline 1996 & -1.0 & 2.3 & 1.7 & 2.8 & 3.4 \\
\hline 1997 & -1.7 & 0.4 & 5.7 & 7.5 & 2.1 \\
\hline
\end{tabular}

(c) Number of Firms in Expansion/Recession

\begin{tabular}{lrrrrrrr}
\hline & 1991 & 1992 & 1993 & 1994 & 1995 & 1996 & 1997 \\
\hline Expansion & 639 & 532 & 460 & 761 & 775 & 756 & 830 \\
$\quad(\%)$ & $(41)$ & $(34)$ & $(30)$ & $(49)$ & $(50)$ & $(49)$ & $(54)$ \\
Recession & 913 & 1,020 & 1,092 & 791 & 777 & 796 & 722 \\
Average sales growth & 0.003 & -0.04 & -0.067 & 0.016 & 0.012 & 0.013 & 0.021 \\
& & & & & & & \\
\hline
\end{tabular}

Notes: Sales and capital are expressed in $10^{6}$ escudos (1995 prices). The total number of firms is 1,552 from an initial sample of 1,970 firms taken from the Central de Balanços of the Bank of Portugal for the period 1990-1997. A firm is in expansion if the log growth of sales is higher than $2 \%$. Full description of the data can be found in section 2 . 
Table 2: Augmented Dickey-Fuller (ADF) and Dickey-Pantula Univariate Tests, 1977:1-1997:4

\begin{tabular}{|c|c|c|c|c|c|c|}
\hline \multirow[t]{2}{*}{ Series } & \multicolumn{2}{|c|}{$\begin{array}{l}\text { Augmented Dickey-Fuller } \\
\text { Ho: } \mathrm{y}_{\mathrm{t}} \sim \mathrm{I}(1) \\
\text { H1: } \mathrm{y}_{\mathrm{t}} \sim \mathrm{I}(0)\end{array}$} & \multicolumn{2}{|c|}{$\begin{array}{l}\text { Dickey-Pantula } \\
\text { Ho: } \mathrm{y}_{\mathrm{t}} \sim \mathrm{I}(2) \\
\text { H1: } \mathrm{y}_{\mathrm{t}} \sim \mathrm{I}(1)\end{array}$} & \multicolumn{2}{|c|}{$\begin{array}{l}\text { Dickey-Pantula } \\
\text { Ho: } \mathrm{y}_{\mathrm{t}} \sim \mathrm{I}(1) \\
\text { H1: } \mathrm{y}_{\mathrm{t}} \sim \mathrm{I}(0)\end{array}$} \\
\hline & $\begin{array}{ll}\mathrm{t} & \text { lags }\end{array}$ & $\mathrm{F}(4, \mathrm{~T})$ & lags & $\mathrm{F}(4, \mathrm{~T})$ & $\begin{array}{ll}\mathrm{t} & \text { lags }\end{array}$ & $\overline{F(4, T)}$ \\
\hline 1 & \begin{tabular}{|ll}
-1.38 & $1,2,3,5$
\end{tabular} & 1.24 & $\begin{array}{|ll|}-6.33 & 1,2,4 \\
\end{array}$ & 1.07 & \begin{tabular}{|ll}
-1.68 & $1,3,4$
\end{tabular} & 1.55 \\
\hline $\mathrm{y}$ & $\begin{array}{ll}-2.75 & 2,3\end{array}$ & 1.20 & -4.49 & 0.69 & $\begin{array}{ll}-2.29 & 1\end{array}$ & 1.53 \\
\hline$p / w$ & $\begin{array}{|ll|}-2.90 & 3,4,5 \\
\end{array}$ & 1.37 & $\begin{array}{|ll|}-7.94 & 4\end{array}$ & 0.79 & $\begin{array}{|ll|}-2.43 & 4\end{array}$ & 0.89 \\
\hline
\end{tabular}

Notes: The ADF equation is $\Delta z_{t}=\alpha+B_{0} z_{t-1}+\sum_{i=1}^{k} \beta_{i} \Delta z_{t-i}+\delta T+u_{t}$, and the null hypothesis is that the series are not stationary $\left(B_{0}=0\right)$. The lag structure is such that the errors are white noise. The $\mathrm{F}(4, \mathrm{~T})$ statistic tests for the presence of fourth order serial correlation in the residuals of the ADF equation (the null is absence of autocorrelation). MacKinnon critical values for the ADF test are -4.04 and -3.45 at $1 \%$ and 5\%, respectively. The auxiliary equations for the Dickey-Pantula test of Ho: I(2)

against H1:I(1), and Ho: I(1) against H1: I(0) are, respectively, $\Delta\left(\Delta z_{t}\right)=\alpha_{0}+\alpha_{1} \Delta z_{t-1}+\sum_{i=1}^{k} \beta_{i} \Delta\left(\Delta z_{t-i}\right)+\delta T+u_{t}$ and $\Delta\left(\Delta z_{t}\right)=\alpha_{0}+\alpha_{2} z_{t-1}+\alpha_{3} \Delta z_{t-1}+\sum_{i=1}^{k} \gamma_{i} \Delta\left(\Delta z_{t-i}\right)+\delta T+u_{t}$. The t-values on $\alpha_{1}$ and $\alpha_{2}$ follow a non-standard DF distribution. $l$ denotes employment, $y$ output, and $p / w$ the relative input price of energy (in logs). The sample period is 1977:1-1997:4. 
Table 3: The Short- and Long-Run Components of Employment: OLS Regressions of Observed Employment $\left(l_{t}\right)$ on Predicted Employment Levels $\left(\hat{l}_{t}, \hat{l}_{t}^{L R}\right.$, and $\left.\hat{l}_{t}^{S R}\right)$

\begin{tabular}{|c|c|c|c|c|c|}
\hline \multirow[b]{2}{*}{ Variables } & \multirow{2}{*}{$\frac{l_{t} \text { on } \hat{l}_{t}}{\text { Coefficient }}$} & \multirow{2}{*}{$\frac{l_{t} \text { on } \hat{l}_{t}^{L R}}{\text { Coefficient }}$} & \multicolumn{2}{|c|}{$l_{t}$ on $\hat{l}_{t}^{L R}$ and $\hat{l}_{t}^{S R}$} & \multirow{2}{*}{$\frac{l_{t} \text { on } \hat{l}_{t}^{S R}}{\text { Coefficient }}$} \\
\hline & & & Coefficient & Partial $\mathrm{R}^{2}$ & \\
\hline$\hat{l}_{t}$ & $\begin{array}{c}0.98 \\
(0.03)\end{array}$ & & & & \\
\hline$\hat{l}_{t}^{L R}$ & & $\begin{array}{c}1.00 \\
(0.04)\end{array}$ & $\begin{array}{c}1.00 \\
(0.03)\end{array}$ & 0.93 & \\
\hline$\hat{l}_{t}^{S R}$ & & & $\begin{array}{c}0.43 \\
(0.16)\end{array}$ & 0.11 & $\begin{array}{c}0.51 \\
(0.61)\end{array}$ \\
\hline Constant & $\begin{array}{l}26.9 \\
(27.6)\end{array}$ & $\begin{array}{l}-7.82 \\
(36.8)\end{array}$ & $\begin{array}{l}-5.61 \\
(35.1)\end{array}$ & & $\begin{array}{l}1052.6 \\
(5.17)\end{array}$ \\
\hline $\mathrm{R}^{2}$ & 0.94 & 0.93 & 0.94 & & 0.01 \\
\hline
\end{tabular}

Notes: $l_{t}$ is actual employment; $\hat{l}_{t}$ and $\hat{l}_{t}^{L R}$ are the predicted values obtained, respectively, from the error correction model and the long run cointegrating relationship; and $\hat{l}_{t}^{S R}$ is the difference between $\hat{l}_{t}$ and $\hat{l}_{t}^{L R}$. All variables are in levels, not log levels. Standard errors in parenthesis. 
Table 4: First-Difference Estimates of Labor Demand (Dependent variable: Employment ${ }_{i t}$; all variables in first differences)

\begin{tabular}{|c|c|c|}
\hline & Basic model & With cycle dummy \\
\hline Employment i (t-1) & $\begin{array}{c}0.746 \\
(0.069)\end{array}$ & $\begin{array}{c}0.757 \\
(0.071)\end{array}$ \\
\hline Labour cost $_{\text {it }}$ & $\begin{array}{l}-0.572 \\
(0.397)\end{array}$ & $\begin{array}{l}-0.585 \\
(0.037)\end{array}$ \\
\hline Labour cost $\mathrm{i}(\mathrm{t}-1)$ & $\begin{array}{c}0.397 \\
(0.036)\end{array}$ & $\begin{array}{c}0.404 \\
(0.037)\end{array}$ \\
\hline Price of materials $s_{\text {it }}$ & $\begin{array}{l}-0.247 \\
(0.043)\end{array}$ & $\begin{array}{l}-0.233 \\
(0.043)\end{array}$ \\
\hline Price of materials $s_{i}(t-1)$ & $\begin{array}{c}0.222 \\
(0.043)\end{array}$ & $\begin{array}{c}0.216 \\
(0.045)\end{array}$ \\
\hline Capital $_{\text {it }}$ & $\begin{array}{c}0.062 \\
(0.067)\end{array}$ & $\begin{array}{c}0.050 \\
(0.075)\end{array}$ \\
\hline Shock $_{\text {it }}$ & $\begin{array}{c}0.470 \\
(0.085)\end{array}$ & $\begin{array}{c}0.370 \\
(0.180)\end{array}$ \\
\hline Cycle x employment i (t-1) & - & $\begin{array}{c}0.0015 \\
(0.0065)\end{array}$ \\
\hline Cycle $\mathrm{x}$ shock it & - & $\begin{array}{c}0.129 \\
(0.283)\end{array}$ \\
\hline $\mathrm{m}_{2}$ & 0.679 & 0.2884 \\
\hline Wald & $1027.5[7]$ & $972.5[9]$ \\
\hline Sargan & $29.6[26]$ & $29.1[24]$ \\
\hline SER & 0.121 & 0.121 \\
\hline \multicolumn{3}{|l|}{ Long-run elasticities: } \\
\hline $\begin{array}{l}\text { labour cost } \\
\text { price of materials } \\
\text { shock }\end{array}$ & $\begin{array}{c}-0.71 \\
-0.10 \\
0.03\end{array}$ & \\
\hline
\end{tabular}

Notes: The equations were estimated using the DPD software, developed by Arellano and Bond (1991). The version used in the study was made available by Dr. Jurgen Doornik of the Oxford University Institute of Economics and Statistics. Asymptotic standard errors robust to general cross-section and time-series heteroskedasticity are given in parentheses. The lagged dependent variable and the input prices (labour and materials) have been instrumented using lags of these variables dated ( $\mathrm{t}-2)$ and earlier as instruments, $\mathrm{m}_{2}$ is a test for lack of second order serial correlation in the first difference residuals, Wald is a test of joint significance of the independent variables, and Sargan is a test for overidentifying restrictions from instruments (degrees of freedom for $\chi^{2}$ statistics are in brackets). The $\mathrm{m}_{2}$ and Wald tests are both asymptotically robust to general heteroskedasticity. SER is the s.e. of the regression. The regression includes time dummies and the sample period is 1994-1997 (1,552 firms). The total number of useable observations is $6,208(1,552 \times 4)$. 
Appendix Table 1: Comparative Statistics

(a) Annual Growth Rates of Employment in the Sample and for Manufacturing Industry, 1990-97

\begin{tabular}{cccc}
\hline & \multicolumn{2}{c}{ Annual growth rate of employment } \\
Sample & Manufacturing & $\begin{array}{c}\text { Proportion of flexible workers } \\
\text { Manufacturing }\end{array}$ \\
\hline 1990 & - & - & 16.8 \\
1991 & -1.2 & -2.3 & 14.9 \\
1992 & -2.4 & -2.5 & 12.5 \\
1993 & -3.4 & -4.8 & 10.9 \\
1994 & -2.8 & -0.7 & 10.3 \\
1995 & -0.9 & -3.6 & 10.8 \\
1996 & -1.0 & -2.6 & 8.9 \\
1997 & -1.7 & -1.8 & - \\
\hline
\end{tabular}

(b) Employment Shares by Sector in the Sample and for Manufacturing Industry

\begin{tabular}{rcc}
\hline $\begin{array}{r}\text { Sector } \\
\text { Identifier }\end{array}$ & Sample & Manufacturing \\
\hline 15 & $16.0 \%$ & $11.3 \%$ \\
$17-19$ & 33.8 & 32.2 \\
$20-22$ & 9.1 & 12.4 \\
$24-25$ & 6.7 & 12.3 \\
$26-28$ & 16.2 & 12.0 \\
$29-33$ & 12.9 & 8.3 \\
$34-35$ & 2.1 & 5.2 \\
36 & 3.2 & 6.3 \\
Total & 100 & 100 \\
\hline
\end{tabular}

Notes: The employment shares in the manufacturing sector are only for 1997. The proportion of flexible workers is based on Relatórios e Análises, Ministry of Labour (various issues). 
Figure 1: Output, Employment, and the Relative Input Price of Energy

(a) Levels of the variables (in logs)
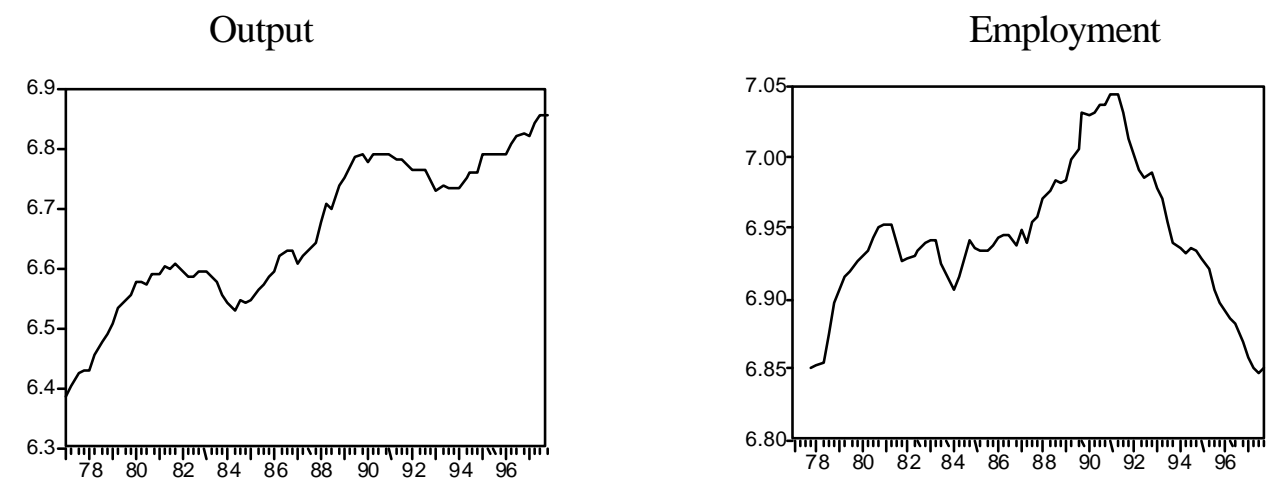

Relative input price of energy (p/w)

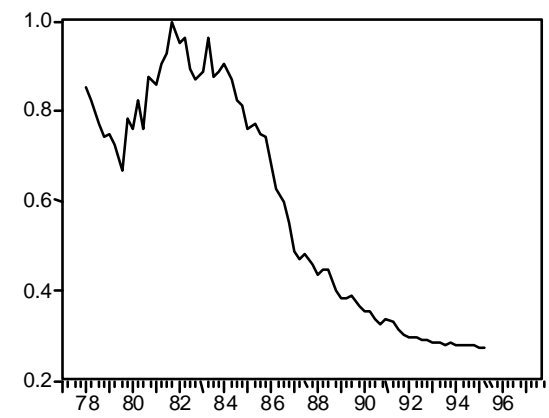

(b) First differences
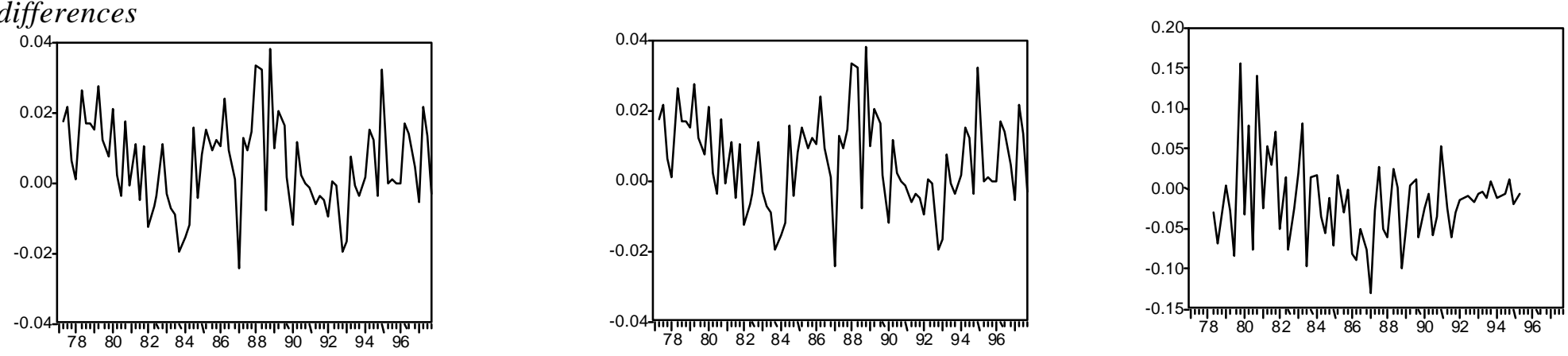
(c) Fourth Differences

Output

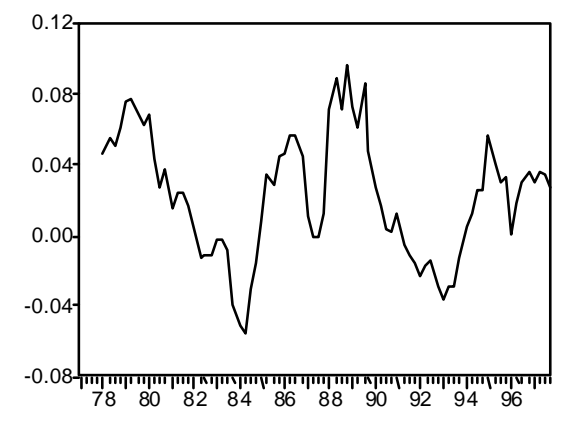

Employment

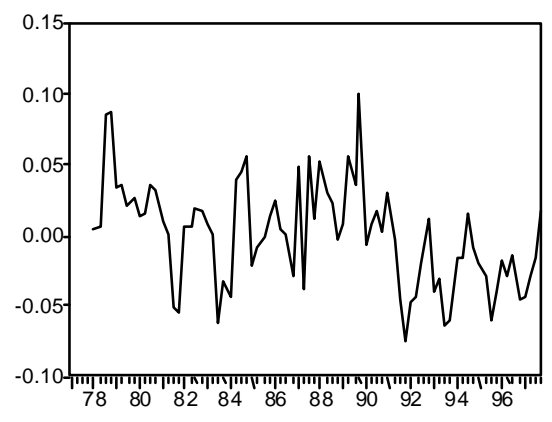

Relative input price of energy (p/w)

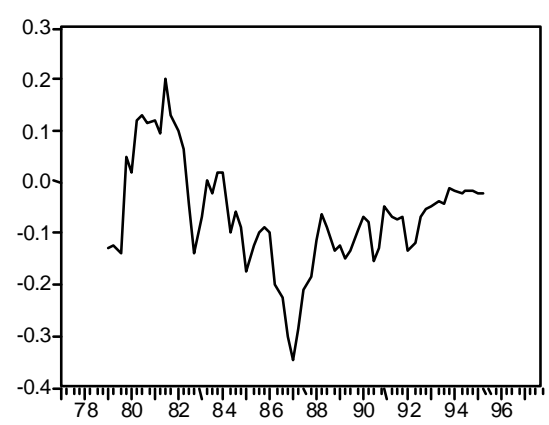


Figure 2: Employment $\left(l_{t}\right)$ and Predicted Employment $\left(\hat{l}_{t}, \hat{l}_{t}^{L R}\right.$, and $\left.\hat{l}_{t}^{S R}\right)$

(a) $l_{t}$ and $\hat{l}_{t}$

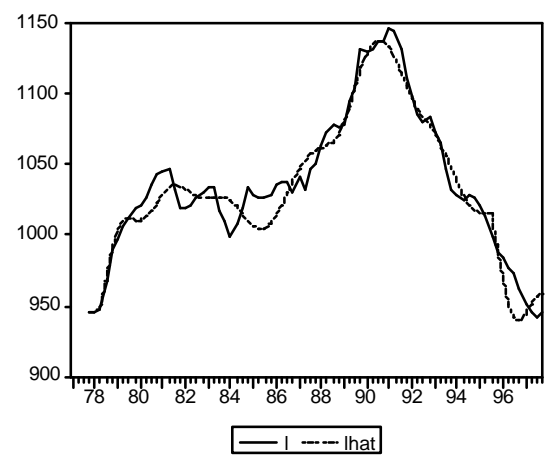

(b) $l_{t}$ and $\hat{l}_{t}^{L R}$

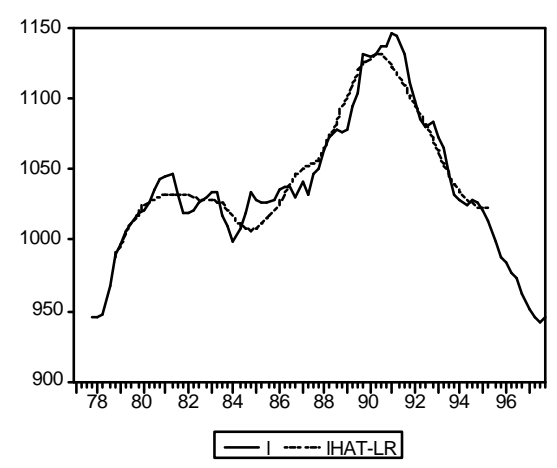

(c) $\hat{l}_{t}^{S R}$

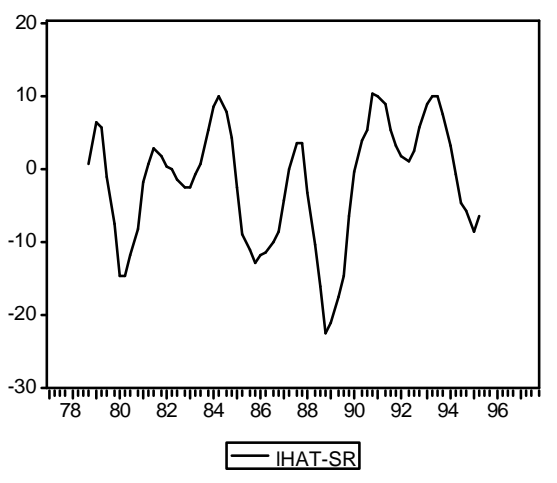

Notes: $l_{t}$ is actual employment; $\hat{l}_{t}$ and $\hat{l}_{t}^{L R}$ are the predicted values obtained, respectively, from equation (2') and the long run cointegrating relationship (equation (1)); and $\hat{l}_{t}^{S R}$ is the difference between $\hat{l}_{t}$ and $\hat{l}_{t}^{L R}$. All variables are in levels, not log levels. 


\section{IZA Discussion Papers}

No. Author(s)

377

S. J. Trejo

378

D. Clark

R. Fahr

379

380

381

382

383

384

385

386

387

388

389

390

391

D. Sliwka
H. Antecol

D. A. Cobb-Clark

M. Sattinger

J. T. Addison

P. Teixeira

L. Goerke

D. Blau

E. Tekin

D. Acemoglu

J.-S. Pischke

A. Ichino

R. T. Riphahn

J. Wagner

C. Schnabel

A. Kölling

C. Grund

L. Farrell

M. A. Shields

T. Beissinger

H. Egger

T. Beissinger

J. T. Addison

P. Teixeira
Title

Area

Date

Intergenerational Progress of Mexican-Origin

1

$10 / 01$

Workers in the U.S. Labor Market

The Promise of Workplace Training for Non-

College-Bound Youth: Theory and Evidence

from German Apprenticeship

The Sexual Harassment of Female Active-Duty

5

$10 / 01$

Personnel: Effects on Job Satisfaction and

Intentions to Remain in the Military

A Kaldor Matching Model of Real Wage

7

$10 / 01$

Declines

The Economics of Employment Protection

$10 / 01$

Tax Evasion in a Unionised Economy

$11 / 01$

The Determinants and Consequences of Child

3

Care Subsidies for Single Mothers

Minimum Wages and On-the-Job Training

$11 / 01$

The Effect of Employment Protection on Worker

11/01 Effort: A Comparison of Absenteeism During and After Probation

Threshold Values in German Labor Law and Job

Dynamics in Small Firms: The Case of the

Disability Law

The Impact of Wage Increases on Job

Satisfaction - Empirical Evidence and

Theoretical Implications

Child Expenditure: The Role of Working

3

$11 / 01$

Mothers, Lone Parents, Sibling Composition and

Household Provision

Dynamic Wage Bargaining if Benefits are Tied to Individual Wages

3

$11 / 01$

11/01

1

$1 / 01$

The Impact of Labor Market Reforms on Capital 2

$11 / 01$

Flows, Wages and Unemployment

Employment Adjustment in Portugal: Evidence $\quad 1$

$11 / 01$ 